\title{
Magmaclasts in Kimberlite
}

\author{
Kimberley J. Webb ${ }^{1}$ and Casey M. Hetman ${ }^{2}$ \\ ${ }^{1}$ Mineral Services Canada Inc., North Vancouver, Canada, kimberley.webb@mineralservices.com \\ ${ }^{2}$ SRK Consulting (Canada) Inc., Vancouver, Canada, chetman@srk.com
}

\section{Introduction}

Despite their widespread occurrence, magmaclasts are perhaps the most enigmatic of kimberlite components; they are diverse in character, usually best or only discerned microscopically and display overlap in characteristics between types, further complicating their identification and interpretation. Yet magmaclasts can serve as powerful tools in kimberlite exploration and evaluation. Here we explain the importance of magmaclasts in economic kimberlite geology and provide an updated set of descriptors (Fig.1, after Webb 2006) that highlights the features used to identify magmaclasts and to discriminate between magmaclast types, as well as between magmaclasts and other clast types (Fig.2).

\section{Definition}

Magmaclast is a descriptive term for physically-distinct, fluidal-shaped bodies of kimberlite magma (now solidified) formed by any process of magma disruption prior to solidification, typically during near-surface emplacement. It is used as an interim term until further investigation of the magmaclast characteristics and magmaclast-bearing rock allow for interpretation of the magma disruption process, and hence classification of the magmaclasts (Scott Smith et al. 2013) as either:

1) melt segregations (Fig.2a), which form non-explosively by magmatic segregation in subvolcanic and non-volcanic hypabyssal intrusions, or

2) melt-bearing pyroclasts (Fig.2b,c), which form by fragmentation and rapid cooling of magma during explosive volcanic eruptions and occur in volcaniclastic rocks above and below surface.

The need for a descriptive interim term arises from the potential for either of these types to occur and the common difficulty in discriminating them, especially at initial broad scales of observation, and due to the high degrees of alteration typical of many kimberlites. 'Former' and 'now solidified' are implicit in application of 'magma' to lithified rocks and 'clast' is used in the broadest sense possible. Autoliths, accretionary clasts (Fig.2d, e) and epiclasts are not magmaclasts, and distinguishing these from magmaclasts is important although not always straightforward. In addition, misleading pseudomagmaclasts (Fig.2f) may be produced by pervasive alteration of groundmass in coherent rocks.

\section{Importance of magmaclasts}

The presence of magmaclasts indicates that a certain degree of modification of the intruded magma has taken place, potentially impacting the inherent diamond content and size frequency distribution. In volcanic environments, the extent of modification and processes involved (e.g. sorting, fines removal) are reflected in part by the distribution, size and physical characteristics of melt-bearing pyroclasts. Magmaclasts are used in the identification of parental magma type, the textural-genetic classification of the infills of kimberlite bodies (and the associated predictions of body size, geometry and internal variability), and in the recognition of and discrimination between different phases of kimberlite in a body. These allow for reconstruction of the emplacement history of a kimberlite and development of valid geological models for resource estimation. Misclassification or lack of attention to magmaclasts, from exploration to mine planning, have resulted in lost dollars and opportunities.

\section{Description and identification}

Magmaclasts comprise entrained solids (crystal, lithic) and groundmass (melt solidification products \pm exsolved fluids). They have fluidal shapes resulting from low melt viscosity and surface tension processes. Melt segregations and melt-bearing pyroclasts are distinguished primarily based on shape (especially range thereof), groundmass crystallinity, and nature of the intermagmaclast material, as well as features such as mineral alignment and vesicularity. Distinctive melt-bearing pyroclast 
assemblages typically characterise the two main classes of pyroclastic kimberlite, Kimberley-type pyroclastic kimberlite and Fort à la Corne-type pyroclastic kimberlite (KPK and FPK, respectively; Scott Smith et al. 2013), although overlap is observed. They differ in shape, proportion of cored to uncored varieties, thickness of rims, groundmass crystallinity, the nature of margins and vesicularity.

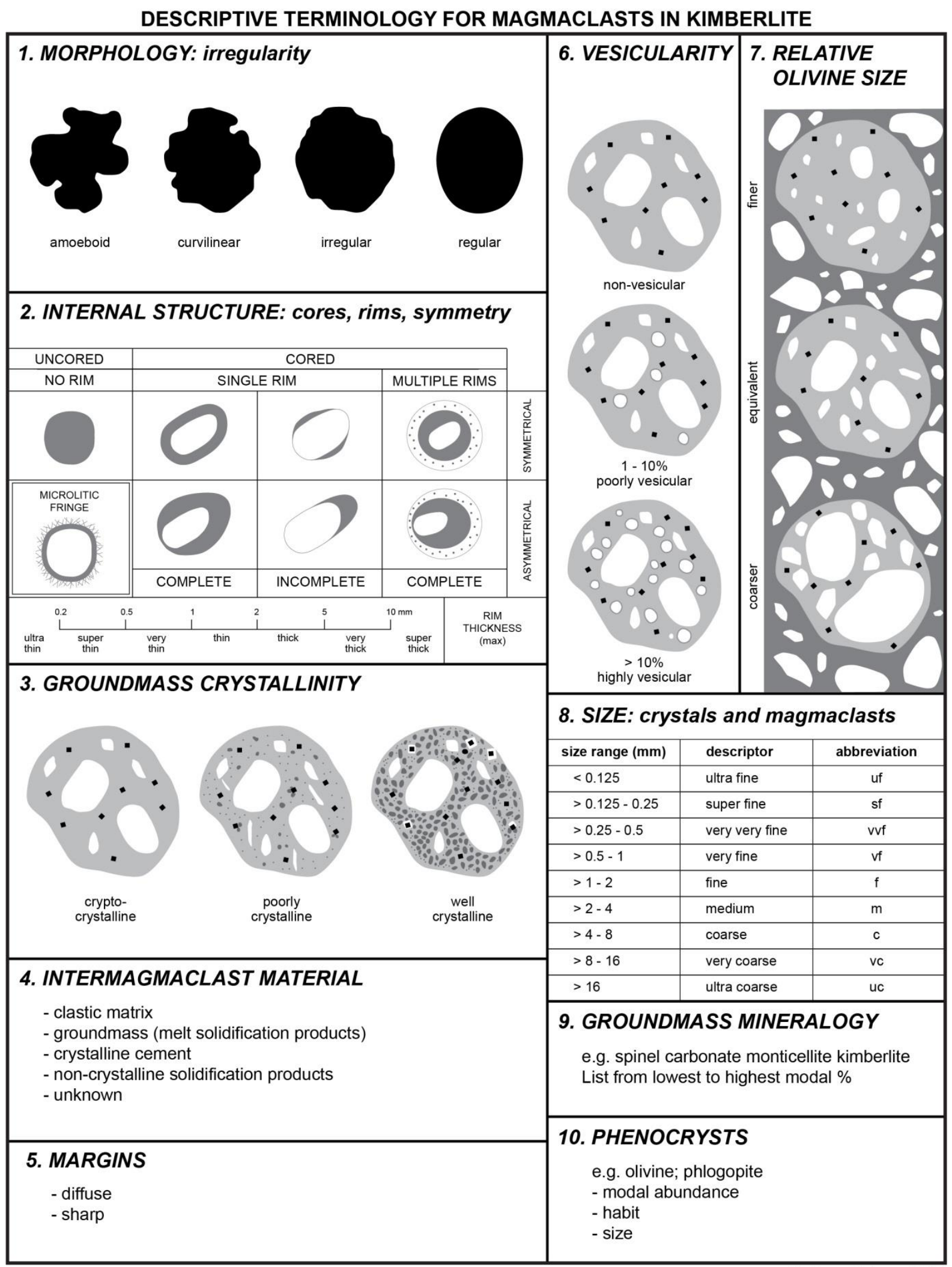

Figure 1: Descriptive terminology for magmaclasts in kimberlite (after Webb 2006).

Webb and Hetman (2017) 


\section{Interpretation}

Description of the characteristics of magmaclasts represented in Fig. 1, combined with other textural, component and structural aspects of a kimberlite, forms the foundation of valid interpretations of the textural-genetic classification, intrusive or volcanic spatial context and emplacement processes (Scott Smith et al. 2013).
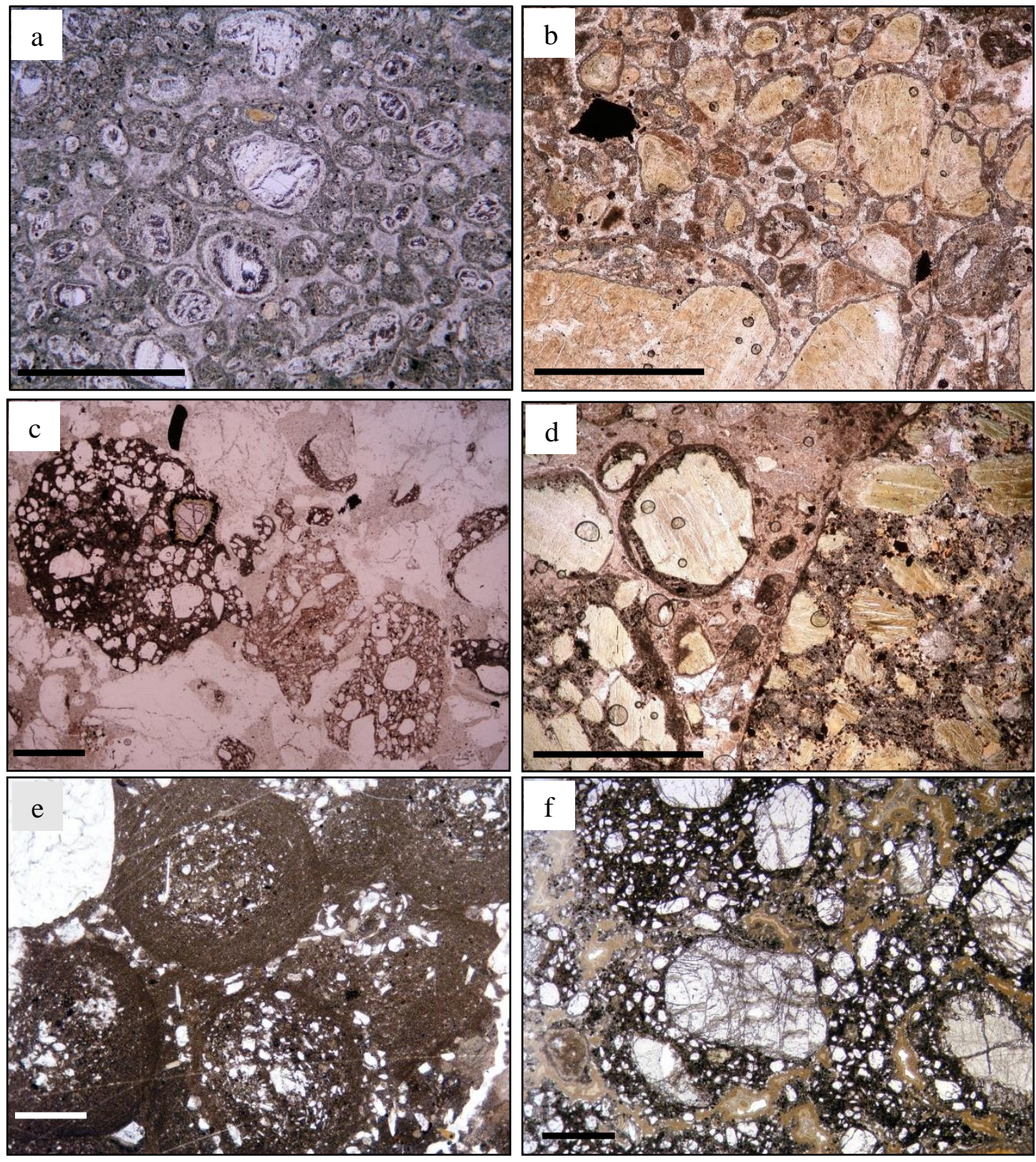

Figure 2: Photomicrographs illustrating diverse characteristics of magmaclasts $(a, b, c)$ and other types of clasts $(\mathrm{d}, \mathrm{e}, \mathrm{f})$ : melt segregations in Wales Island hypabyssal kimberlite (a); melt-bearing pyroclasts in Dutoitspan (Kimberley) KPK (b) and in Fort à la Corne (Body 122) FPK (c); coherent autolith (right) in Letseng KPK (d), accretionary clasts in A418 at Diavik (e) and pseudomagmaclasts in the Rat dyke, Ekati (f). Scale bars $=1 \mathrm{~mm}$.

\section{References}

Scott Smith BH, Nowicki TE, Russell JK, Webb KJ, Mitchell RH, Hetman CM, Harder M, Skinner EMW, Robey JV (2013) Kimberlite terminology and classification. Proceedings of the $10^{\text {th }}$ International Kimberlite Conference. Special Issue J Geol Soc India, 2:1-17. Springer India.

Webb KJ (2006) Juvenile clasts in kimberlites: standardized comprehensive description towards unraveling emplacement mechanisms. In: Long Abstracts of the 8IKC Kimberlite Emplacement Workshop, Saskatoon, Canada, September 2006. 